\title{
STUDYING POLITICAL COMMUNITIES IN VK.COM WITH NETWORK ANALYSIS
}

\author{
Ilya A. Bykov ${ }^{1}$, Denis S. Martyanov ${ }^{2}$ \\ St Petersburg State University. Saint Petersburg, Russia
}

\begin{abstract}
The study explores politicized virtual communities of Russia in the VK.com within the social network analysis approach. The paper focuses on the VK since it is the largest social networking service in Russia. The authors aim to draw a general map of virtual communities in the VK which are politically engaged and represent all political ideologies in Russia. The data were collected with help of the VK API in 2019. Based on the specially designed algorithm, the authors have collected a sample of 115 politicized communities. The paper presents a critical analysis of the implementation of data sampling and crawling. The authors argue that this study includes all significant virtual communities from a full range of ideologically and politically oriented discussion groups to institutionalized political actors such as political parties and government agencies, including groups of leading Russian mass media. The authors apply the Gephi network analysis and visualization software package, a leading social network analysis software, to produce a map of the political virtual communities in Russia. The study indicates that virtual communities of mass media and the institutionalized communities, such as political parties or government institutions, have concentrated at the core of the graph. At the same time, discussion groups about ideologies were in the periphery of the graph.
\end{abstract}

\section{Keywords}

virtual communities; echo-chambers; political ideologies, political communication; me-diatization; Russia; social media; VK; Gephi; SNA

\section{(c) (1)}

This work is licensed under a Creative Commons «Attribution» 4.0 International License

1 Email: i.bykov[at]spbu.ru

2 Email: martyanoff[at]mail.ru 


\title{
ИССЛЕДОВАНИЕ ПОЛИТИЗИРОВАННЫХ ВИРТУАЛЬНЫХ СООБЩЕСТВ ВО ВКОНТАКТЕ: СЕТЕВОЙ ПОДХОД
}

\author{
Быков Илья Анатольевич ${ }^{1}$, Мартьянов Денис Сергеевич $^{2}$ \\ Санкт-Петербургский государственный университет. Санкт-Петербург, Россия
}

\section{Аннотация}

Статья посвящена исследованию политизированных виртуальных сообществ в социальной сети Вконтакте с помощью сетевого подхода. Исследование сосредоточено на социальной сети Вконтакте, поскольку именно эта социальная сеть является самой популярной в России. Основная цель статьи заключается в создании карты политизированных виртуальных сообществ, репрезентативной всем политическим направлениям в социальной сети. На основе разработанного алгоритма авторы создали выборку из 115 политизированных сообществ. Собранные данные отражают состояние на 2019 год. В статье приводится подробный анализ методов и процедуры сбора данных. Авторы доказывают, что представленный алгоритм составления выборки носит репрезентативный характер. Для визуализации данных о связях между политизированными группами использовался открытый программный пакет для сетевого анализа Gephi. Полученная карта политизированных виртуальных сообществ позволяет сделать вывод о том, что в центре сети находятся такие институционализированные группы, как политические партии, СМИ и некоторые государственные структуры (МИД, Государственная Дума, Роскосмос и др.). Неинституционализированные (дискурсивные) виртуальные сообщества находятся на периферии полученного графа, что говорит о том, что самоорганизованные группы, осуществляющие обсуждение политических проблем без организационной поддержки, находятся в невыигрышном положении.

\section{Ключевые слова}

виртуальные сообщества; эхо-камеры; политические идеологии; политическая коммуникация; Россия; социальные медиа; Вконтакте; сетевой анализ; Gephi

Это произведение доступно по лицензии Creative Commons «Attribution» («Атрибуция») 4.0 Всемирная

1 Email: i.bykov[at]spbu.ru

2 Email: martyanoff[at]mail.ru 


\section{INTRODUCTION}

This study aims to draw a map of politically engaged virtual communities in Russia. The paper focuses on the VK.Com (formerly known as 'Vkontakte') for it is the largest social networking service in Russia according to Alexa.com. One may think that this aim looks technically oriented. It is partially true because this research is a part of the broader research project (Martyanov, 2019). However, the study includes several original topics like what virtual communities are or how they fit into the context of mediatized politics today. We intend to explicate our definitions and topics in the following parts of the paper.

\section{VIRTUAL COMMUNITIES, POLITICS, AND MEDIATIZA- TION}

In this study, we define the 'virtual community' applying the communicative approach, which is primarily based on the works of G. Rheingold and B. Wellman (Wellman, 1998). According to Rheinhold, virtual community is a 'social entity that is formed on the basis of computer-mediated communication, has enough people to support communication for a long time, and, at the same time, includes some human emotions and, as a result, has a network of interpersonal relationships' (Rheinhold, 2000). It seems like this definition is too general. S. Herring suggests for any virtual community to qualify it must have the following parameters: (1) active 'self-sustaining' participation and the core of regular participants; (2) a common history, purpose, culture, norms, and values; (3) solidarity, support, reciprocity; (4) conflict resolution methods; (5) self-awareness of the group as a subject, different from other groups; (6) the emergence of roles, hierarchies, governance, rituals (Herring, 2004, 316338).

In Russian media studies, the 'internet-group' term is quite popular. However, in this research, we prefer to use a traditional virtual community approach for it summarizes key characteristics of the phenomenon much better. There are too many groups in VK with no shared values or meaningful communication. So, we suggest using the following main features of virtual communities: (1) unifying interest; (2) computer-mediated communication; (3) shared values (Martyanov, 2017). The unifying interest serves not only as of the main motivation for participation in the virtual community but also substitutes for territorial identity as the core feature of traditional local communities (Zheng, 2020). And if the latter is itself determined by the individual's place of residence, then in the case of virtual communities and unifying interest, interest precedes the location and it forms the communicative space in 
which the community members subsequently interact. Computer-mediated communication is not only technological but also organizational and discursive. Internet communication contributes to the formation of a specific discourse, which not only sets the rules of behavior in the community but also structures it, creates a hierarchy. The third component is more characteristic of developed and active virtual communities and serves as a kind of indicator for group cohesion. A given community without values is only a formal structure.

Numerous studies have been conducted on the problems of online political communication and virtual communities. Very often these studies apply the concept of public sphere founded by J. Habermas to evaluate communication practices. Usually, the public sphere includes voluntary participation, universal access, rational argumentation, and freedom of expression. In his later works, Habermas came to thought that the public sphere has a network nature (Habermas, 2015). Castells suggests with careful optimism that social media and grassroots activism evidenced in the Arab Spring as well as Iceland's 'Kitchenware' Revolution are able to boost democratic development and maintain public sphere with the help of virtual communities (Castells, 2015).

However, recent studies show that there are many signs of malfunctioning of the public sphere as a type of political communication today. Boutyline and Willer argue that instead of freedom of expression and rational argumentation people tend to cooperate and communicate to people with similar political views (Boutyline, 2017). This effect is known as 'echo-champers' or 'information bubbles'. Unlike the public sphere, echo chambers tend to escape discussion and rational argumentation. In echo chambers, communication maintains established beliefs in the virtual community. Echo chambers are the most striking examples of post-truth politics because they seek to ignore 'unfavorable' facts and arguments. Echo chambers ensure the stability of political views. Also, they contribute to the political radicalization and further polarization in society (Sunstein, 2009).

The public sphere could fall into refeudalization when private communication is dominating over public communication (Yun, 2013). It could be done on the macro-level within social media censorship and according to users' agreements or on the micro-level within social practices of selective moderation. Studies show that about half of the users one way or another came across 'malicious' comments on various Internet sources (Suh et all, 2018). Moderators have to substitute legal forms of communication. Moderators have emerged as an informal institution appears in the 'vacuum' of formal institutions (Langvardt, 2018).

Several studies show that virtual communities could be divided into three groups: 'counter-public spaces', 'echo chambers', and 'safe spaces'. Negt 
and Kluge rejected the universality of the public sphere and proposed the concept of 'counter-public spheres', an example of which was the proletarian public sphere, opposed to the Habermas bourgeois sphere (Negt, 1993). This concept reveals the heterogeneity of society and the conflict of communication in it. The idea of 'safe spaces' refers to homogeneous communities with no rational discussion but with common experience, typically involving situations of discrimination or violence (Click, 2019). For many network users, such communities are an opportunity to share their pain with others and feel solidarity. 'Safe spaces' also constitute the intentional exclusion of 'others' that could harm community members in their own words. First of all, such communities are about support and psychological assistance. But at the same time, such places become the field of activity of the 'social justice warriors' as the most aggressive activists of such communities. Echo chambers tend to have less positive results as 'safe spaces'. Echo chambers are also autonomous and homogeneous spaces in which discussions are aimed at maintaining community-specific values. Echo-chambers are not examples of rational argumentation, they produce a policy of post-truth or emo-truth (Harsin, 2017). 'Safe spaces' and echo-chambers are close phenomena that are quite similar in a communicative sense. However, in terms of political discourse, they are almost polar categories since the former are used to label communities of 'real victims' while the latter are used to label the dominant class who pretend to be 'real victims'. Gibson has found that in 'safe spaces' both moderator's removal of posts and self-removal of posts under group pressure are faster than in other groups. He also has found that in 'safe spaces' users are less crude than in spaces of the public sphere (Gibson, 2019).

The virtual communities became an integral part of the media space today heavily participating in the process of the mediatization of politics. Mediatization is the process when the media transform other institutions because they need to adapt to the formats of the media (Kantola, 2014). Without successful information support, social organizations quickly lose their social positions (Aelst, 2012). This means that social actors tend to behave like the media and adjust their activities trying to look attractive to their audiences (HoltzBacha, 2004). Schulz claims that mediatization takes place through a step-bystep process: 'first, the media extend the natural limits of human communication capacities; second, the media substitute social activities and social institutions; third, the media amalgamate with various non-media activities in social life; and fourth, the actors and organizations of all sectors of society accommodate to the media logic' (Schulz, 2004, p. 98). Paradoxically, mediatization relies on the decline of traditional media and is facilitated by the development of new forms of media communication. Today media communication includes not only traditional journalism and mass media but new tools and methods 
like user-generated content, blogging, social media marketing, etc. This process is most profitable for digital platforms such as Apple, Amazon, Microsoft, Google, Facebook, Twitter, and other IT-giants have built an infrastructure for social media and media communication.

\section{METHOD AND DATA}

In this study, a social network analysis is a main research method (Bastian, 2009). It looks like a social network analysis should be very popular as a tool for research of virtual communities and politics. However, in Russia, there are not so many empirical studies in this field. Some studies care about various aspects of network communication, such as network discourse, hashtags, or verbal aggression (Balakhonskaya, 2018). More rarely, researchers try to create an overall picture of political communication in a networked environment but tend to cover fairly limited geographic segments or topics. For example, S. Suslov's research is focused on the network space of St. Petersburg (Suslov, 2016). Respectfully, E. Schekotin and his colleagues identified opposition groups of 'right-wing radicals' and 'supporters of Alexey Navalny' (Shchekotin et al, 2013), while the work of N. Zilberman and N. Mishankin concentrates on the supporters of the 'Soviet idea' (Mishankina \& Zilberman, 2017). There is a good study of the political blogosphere in Russia by B. Etling with colleagues (Etling et al., 2010). Unfortunately, this study is really outdated and also centered around Internet blogs and the LiveJournal era, which obviously relates not only to other political times but also to other technical possibilities. However, it is very interesting to find out, if political virtual communities in Russia are divided as mass media into two large sectors of proKremlin and anti-Kremlin supporters (Toepfl \& Litvinenko, 2018).

So, the first research question (RQ1) is how to build a sample and determine which groups must be investigated and which must not. In our study, at the time of data collection from VK in July 2019, there were about 190 million groups. The question includes data collection from VK using its open API (application programming interface). This is not a simple task because one needs to build an algorithm for automatic detection of political virtual communities to select them from all political spectrum but excluding insignificant groups. At the same time, we sought to ensure that the result included the most diverse ideological discourses so that in the future we would go on to analyze the characteristics of political discussions. As the initial selection criteria, we took only the largest communities (at least 1000 participants), quite active (at least 1 post in the last month), and suggesting the possibility of discussion (comments included). Since one of the requirements of our sample was the presence of comments, not all the largest VK groups were included in our sample. For example, the 'RosPil' ('War with corruption' group by Alexey 
Navalny (https://vk.com/rospil ) was not included in our sample for commenting was closed there.

The second research question (RQ2) is about the structure of the network or graph of virtual communities that are politically engaged and represent all political spectrum in Russia. We are going to perform a social network analysis of inter-community relations with the Gephi program (https://gephi.org/), which is open source software available and proved to be an effective tool for SNA. SNA in itself is a very useful approach for it has great opportunities for visualization which helps to understand the structure of social connections and roles.

The third research question (RQ3) deals with the problem of network segmentation. In other words, does the pro-Kremlin and anti-Kremlin opposition exist in the VK among politicized virtual communities? And, if yes, does this opposition have real significance, and what segment dominates the other? To find this one should apply the modularity test which is a special technique in SNA. The functionality of the modularity test was proposed by Newman and Girvan during the development of clusterization algorithms (Newman, 2004). Modularity is a quantitative measure that indicates the presence of distinct communities within a network. If the network's modularity is high, it means it has a pronounced community structure, which, in turn, means that there's a space for plurality and diversity inside.

\section{RESULTS}

The first time, created with the help of specialists from the Center for Sociological and Internet Research at St. Petersburg State University, the algorithm automatically generated a list of 19,243 groups and pages that met the initial requirements for activity and matching keywords. Manual verification of data in a short time was unreasonable. Therefore, the criteria were somewhat tightened: pages were turned off from the search (only groups were left), the period of activity was reduced (up to 10 days) and the number of subscribers was increased (up to at least 4000 people). As a result of these manipulations, we expected a significant decrease in the total number of groups. And so it happened. The second time the search returned 2693 groups, which were manually evaluated. Nominal communities were excluded from the sample, in which the discussion in the comments was either absent or extremely volatile. Numerous communities were excluded from the sample, which, despite the formal presence of keywords, were not politicized. As a result of manual screening, we only had 65 groups, which, nevertheless, formed a sample in which all the necessary ideological segments were represented. And what is most interesting, in each political segment there were several communities at once. Thus, a spontaneous quotation of the sample occurred. 
The second part of the sample was also generated using the built-in group search mechanism in the VK. The choice of groups was dictated by the in-build categories such as 'media', 'hobbies' (politics), 'political parties', and 'public organizations'. The criteria for activity and the number of subscribers were the same as in the first part of the sample. When choosing groups in the 'Media' category, we use ratings the media-metrics from 'Medialogy' (www.mlg.ru ) and 'MediaScope' (http://mediascope.net ). It turned out that not all major media outlets have official groups in the VK, which we could attribute to virtual communities that would satisfy all the requirements. Some political parties have also been added, but which were not selected by keywords. For example, the LDPR community cannot be found in the search by the keyword 'party' for it is an abbreviation of Liberal-Democratic Party of Russia. For the most interested readers, we suggest a complete list of groups and their segmentation by ideological areas are presented in Figure 1, which is available on the Internet at Github (https:/github.com/bkv-lab/vk-virt-com2019/blob/master/sample.csv ).

Let us repeat that the data were collected in July 2019. The sample includes 115 virtual communities of the largest Russian social network VK. The sample consists of the virtual communities which belong to the recognized ideological discourses: liberal, conservative, social democratic, communist, nationalist, anarchist, feminist, green discourses. As well, it contains the significant 'institutional' communities, which represent the established groups around such institutions as public authorities, political parties, public organizations, and the media. Thus, our sample consisted of two parts: discursive (part 'A') and institutionalized (part 'B'). As a result, we have a representative sample of virtual communities in the VK. The groups in our sample totaled from several thousand to several million members. For example, the RIA Novosti group in VK counted 2 million 407 thousand 319 subscribers, and the 'Lentach' group - 2 million 125 thousand 808 subscribers.

In the resulting indirect graph, the total number of vertices was 115 (according to the number of politicized communities), the total number of edges was 6523 . The average length of the path between the nodes was only 1.005, and the diameter of the graph is 2 , which indicates a high interconnection between groups. The graph density coefficient was 0.995 , which, in our opinion, should be interpreted as a high indicator. The average vertex degree was 113.44, which means that each node is connected to almost all other vertices. This emphasizes the sufficiently high connectivity of the resulting graph. At the same time, the modularity coefficient is only 0.2 , which may indicate a low degree of potential clustering of the graph of politicized communities. Thus, the key metrics indicate that this sample represents all groups of political activists in the VK. 


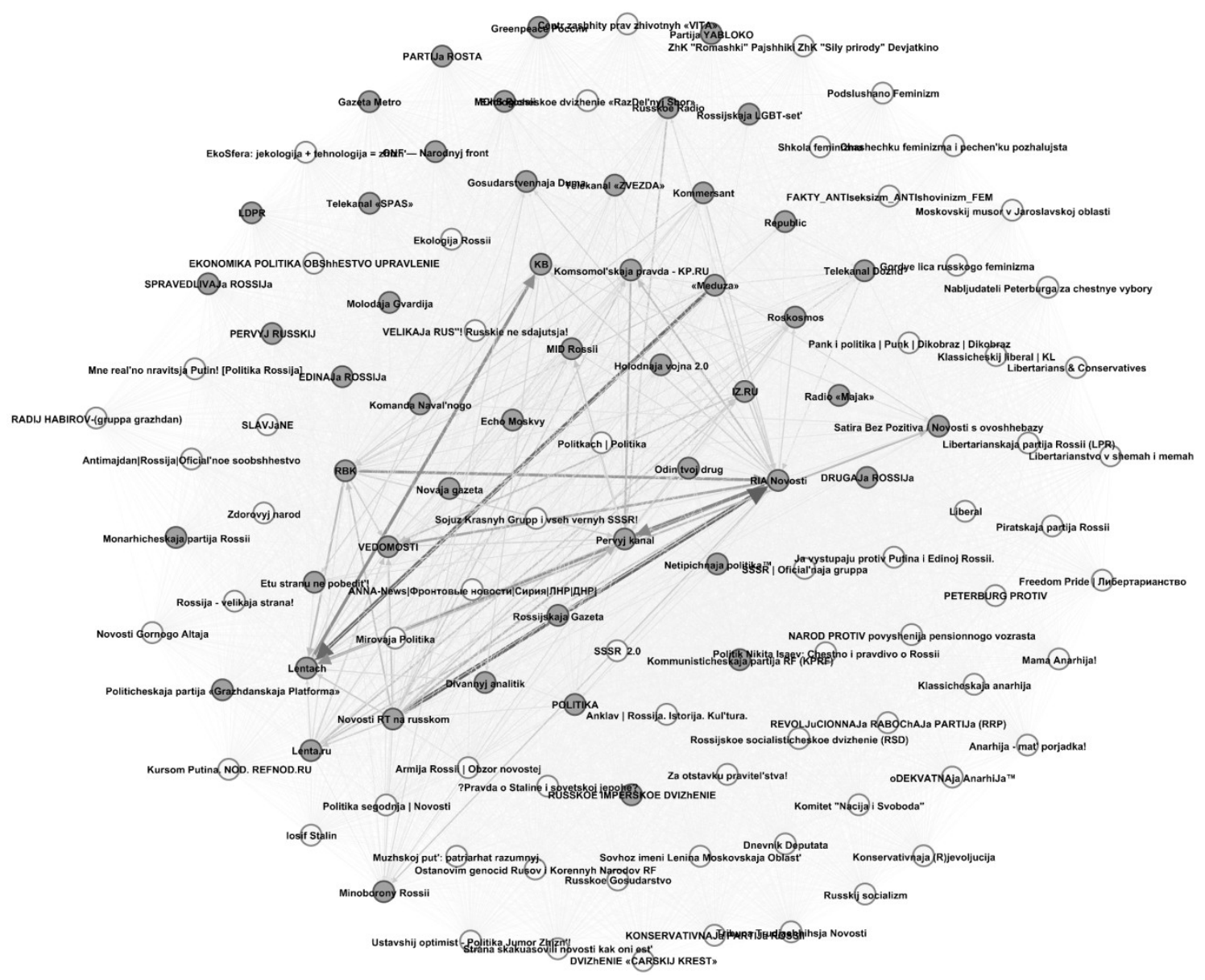

Figure 1. Map of politicized virtual communities in VK, 2019. Source: composed by the authors with Gephi software.

Using the 'Expansion' algorithm the sample was visualized (see fig. 1). In the SNA terminology, it is called a graph. Based on the number of connections between the virtual groups, the algorithm puts more important nodes closer to the center. We can see, that the center of the graph is occupied by the institutionalized communities, and discursive communities are mainly on its periphery. The map of politicized virtual communities of the discursive part of the sample (Part 'A') shows that in the center of the graph are several communities, which can conditionally be attributed to mainstream communities related to foreign policy and patriotic themes. In a sense, we can talk about the presence of a certain central cluster. However, most of the communities are on the periphery of the graph, regardless of the ideological spectrum. This situation is since, against the backdrop of institutionalized interest groups, virtual communities based on the principle of exchange of views are in a weak position. They do not have enough organizational and communication resources to advance on a social network. A completely different picture develops in Part 'B' of the sample: most groups are in the center of the general graph. 
Moreover, most of the central groups are related to the media. Channel One, RIA Novosti, Lentach, Meduza, Ekho Moskvy, Vedomosti, RBK, and other media outlets dominate the graph and form the strongest links. The media have the maximum communication resources to attract the attention of users, while other institutionalized groups such as political parties, ministries, and other official structures can be promoted through organizational resources. Not all visualization results seem clear at first glance. Thus, the 'Yabloko' political party and 'Partiya Rosta' groups are located on the very edge of the graph, almost as far from the center as the Russian Monarchist Movement and the Monarchist Party of Russia. This seemingly surprising fact can be explained quite simply if we look at the number of subscribers and the intensity of communication in groups that were at approximately the same level at the time of the study. Most of the politicized virtual communities from Part 'A' belong to the category of marginal or, speaking more accurately and in terms of the social network analysis, peripheral.

To answer RQ3 we run modularity test. In our case, if the modularity value is 0.51 , we can see the formation of two large segments or clusters in graph. $62.61 \%$ of the communities belongs to the pro-Kremlin ("patriotic) segment, the remaining $37.39 \%$ belongs to the anti-Kremlin ('opposition') segment. This segmentation reminds the division of the information space of Russia into two large sectors described by Toepfl (2018). This modularity test explains why some virtual communities from Part ' $A$ ' of the sample are in the center of the graph: some of them managed to be in the center of the graph because of their correspondence to the political mainstream or to such an ideological discourse, which can be generally called state-patriotic.

\section{CONCLUSION}

The last part of the paper describes some opportunities and limitations of the network analysis for studying politicized virtual communities. It is quite obvious that to build a sample of politicized virtual communities in the VK is a non-trivial task. On the one hand, the sample should not be too large, as this will create very large requirements for data uploading and the need for serious computing power. On the other hand, it is necessary to create such an algorithm that would cover the whole spectrum of political views and ideologies. So, it is understandable that there are not so many attempts to create a big visualization of the virtual space. Our study has been done only with the support of the resource center. Also, the presented technique has serious limitations caused by the VK search mechanism, which works only for the names of groups. However, the use of the keyword method is quite possible and gives a positive result. 
Secondly, under our definition of virtual communities, our sample has only groups with active communication between members about common topics and issues with a significant number of comments to each post. Politics is implemented through the process of political communication. The discursive practices characterize the essence of modern political processes. A network analysis of the politicized virtual communities of Russia in the VK confirms this trend since there are media groups in the center of the graph. It means that the process of mediatization goes steadily.

Unfortunately, the social network approach is not able to bring the essence of communication in virtual communities. It is good for revealing the structure of the political landscape and to some degree for the understanding of social-demographic characteristics of political communities. To find some useful information about real discursive practices in virtual communities one needs to apply discursive analysis. Also, there is a big problem of selective moderation which is a part of modern communication practices and an integral part of the concept of echo chambers that challenges the theory of the public sphere. The SNA in case of detecting selective moderation is not applicable. So, undertaken application of network analysis indicates the importance of system approach and multi-dimensional methodological toolkit.

\section{ACKNOWLEDGMENT}

The reported study was funded by RFBR and EISR according to the research project № 19-011-31001. We would like to express our gratitude to the Center for Sociological and Internet Research at Saint Petersburg State University for helping us to retrieve data from the VK.

\section{References}

Balakhonskaya, L., \& Bykov, I. (2018). Virtual aggression in political blogs of the 'Echo of Moscow'. Vestnik of Saint Petersburg University. Language and Literature, 15(3), 492506. doi: 10.21638/spbu09.2018.313 (In Russian).

Bastian, M., Heymann, S., \& Jacomy, M. (2009). Gephi: An Open Source Software for Exploring and Manipulating Networks. Proceedings of the International AAAI Conference on Web and Social Media, 3(1), 361-362. Retrieved from https://ojs.aaai.org/index.php/ ICWSM/article/view/13937

Boutyline, A., \& Willer, R. (2017). The Social Structure of Political Echo Chambers: Variation in Ideological Homophily in Online Networks. Political Psychology, 38(3), 551-569. doi: https://doi.org/10.1111/pops.12337

Castells, M. (2015). Networks of Outrage and Hope: Social Movements in the Internet Age. Cambridge: Polity Press. 
Click, M. A. (2019). Anti-Fandom: Dislike and Hate in the Digital Age. New York: NY University Press.

Etling, B., Alexanyan, K., Kelly, J., Faris, R., Palfrey, J., \& Gasser, U. (2010, October 18). Public Discourse in the Russian Blogosphere: Mapping RuNet Politics and Mobilization | Berkman Klein Center. Retrieved from Berkman Center Research Publication website: https://cyber.harvard.edu/publications/2010/Public_Discourse_Russian_Blogosphere

Gibson, A. (2019). Free Speech and Safe Spaces: How Moderation Policies Shape Online Discussion Spaces. Social Media + Society, 5(1). doi: 10.1177/2056305119832588

Habermas, J. (2015). Between Facts and Norms: Contributions to a Discourse Theory of Law and Democracy. Massachusetts: John Wiley \& Sons.

Harsin, J. (2017). Trump l'Eil: Is Trump's Post-Truth Communication Translatable? Contemporary French and Francophone Studies, 21(5), 512-522. doi: 10.1080/17 409292.2017.1436588

Herring, S. (2004). Computer-mediated Discourse Analysis: An Approach to Researching Online Communities. Designing for Virtual Communities in the Service of Learning. Cambridge: Cambridge University Press.

Holtz-Bacha, C. (2004). Germany: How the Private Life of Politicians got into the Media. Parliamentary Affairs, 57(1), 41-52. doi: 10.1093/pa/gsh004

Kantola, A. (2014). Mediatization of Power: Corporate CEOs in Flexible Capitalism. Nordicom Review, 35(2), 29-41. doi: 10.2478/nor-2014-0013

Langvardt, K. (2018). Regulating Online Content Moderation. Georgetown Law Journal, 106(5), 1353-1366. Retrieved from https://heinonline.org/HOL/Page? handle=hein.journals $/$ glj106\&id=1367\&div=\&collection $=$

Martyanov, D. (Ed.). (2019). Manageability and discourse of virtual communities in the context of post-factual politics. St Petersburg: ElecSys. (In Russian).

Martyanov, D., \& Bykov, I. (2017). Ideological Segregation in the Russian Cyberspace: Evidences from St. Petersburg. In D. A. Alexandrov, A. V. Boukhanovsky, A. V. Chugunov, Y. Kabanov, \& O. Koltsova (Eds.), Communications in Computer and Information Science (pp. 259-269). Cham: Springer International Publishing. doi: 10.1007/978-3-319-69784-0_22

Mishankina, N., \& Zilberman, N. (2016). "Soviet" in the Space of Social Networks: A Form of Political Reflection. In A. V. Chugunov, R. Bolgov, Y. Kabanov, G. Kampis, \& M. Wimmer (Eds.), Communications in Computer and Information Science (pp. 45-50). Cham: Springer International Publishing. doi: 10.1007/978-3-319-49700-6_6

Newman, M. E. J., \& Girvan, M. (2004). Finding and evaluating community structure in networks. Physical Review E, 69(2), 026 113. doi: 10.1103/PhysRevE.69.026113

Rheingold, H. (2000). The Virtual Community, revised edition: Homesteading on the Electronic Frontier. Cambridge: MIT Press.

Schulz, W. (2004). Reconstructing Mediatization as an Analytical Concept. European fournal of Communication, 19(1), 87-101. doi: 10.1177/0 267323104040696 
Shchekotin, E. V., Goyko, V. L., Baryshev, A. A., \& Kashpur V. V. (2017). Influence of parliamentary elections on mobilization of opposition in Russia. Science Bulletin of Siberia, (3), 90-107. Retrieved from http://sjs2.tpu.ru/journal/article/view/1576 (In Russian).

Suh, K.-S., Lee, S., Suh, E.-K., Lee, H., \& Lee, J. (2018). Online Comment Moderation Policies for Deliberative Discussion-Seed Comments and Identifiability. Fournal of the Association for Information Systems, 19(3), 182-208. Retrieved from https://aisel.aisnet.org/jais/vol19/iss3/2

Sunstein, C. R. (2009). Going to Extremes: How Like Minds Unite and Divide. Oxford University Press.

Suslov, S. (2016). Clusters of St. Petersburg political online communities in VKontakte. Bulletin of St. Petersburg University. Sociology, (4), 69-87. doi: 10.21638/11701/spbu12.2016.405 (In Russian).

Toepfl, F., \& Litvinenko, A. (2018). Transferring control from the backend to the frontend: A comparison of the discourse architectures of comment sections on news websites across the post-Soviet world. New Media \& Society, 20(8), 2844-2861. doi: $10.1177 / 1461444817733710$

Van Aelst, P., Sheafer, T., \& Stanyer, J. (2012). The personalization of mediated political communication: A review of concepts, operationalizations and key findings. fournalism: Theory, Practice \& Criticism, 13(2), 203-220. doi: 10.1177/1464884911427 802

Wellman, B. (1998). Networks In The Global Village: Life In Contemporary Communities. Routledge.

Yun, G. W., Park, S.-Y., Holody, K., Yoon, K. S., \& Xie, S. (2013). Selective Moderation, Selective Responding, and Balkanization of the Blogosphere: A Field Experiment. Media Psychology, 16(3), 295-317. doi: 10.1080/15 213269.2012 .759462

Zheng, S. (2020). Chinese Fans' Patriotism Creating Quandary in the Digital Media Era. Galactica Media: fournal of Media Studies, 2(4), 87-111. doi: 10.46539/gmd.v2i4.87

\section{Список литературы}

Bastian, M., Heymann, S., \& Jacomy, M. (2009). Gephi: An Open Source Software for Exploring and Manipulating Networks. Proceedings of the International AAAI Conference on Web and Social Media, 3(1), 361-362. Retrieved from https://ojs.aaai.org/index.php/ ICWSM/article/view/13 937

Boutyline, A., \& Willer, R. (2017). The Social Structure of Political Echo Chambers: Variation in Ideological Homophily in Online Networks. Political Psychology, 38(3), 551-569. doi: https://doi.org/10.1111/pops.12337

Castells, M. (2015). Networks of Outrage and Hope: Social Movements in the Internet Age. Cambridge: Polity Press.

Click, M. A. (2019). Anti-Fandom: Dislike and Hate in the Digital Age. New York: NY University Press. 
Etling, B., Alexanyan, K., Kelly, J., Faris, R., Palfrey, J., \& Gasser, U. (2010, October 18). Public Discourse in the Russian Blogosphere: Mapping RuNet Politics and Mobilization | Berkman Klein Center. Retrieved from Berkman Center Research Publication website: https://cyber.harvard.edu/publications/2010/Public_Discourse_Russian_Blogosphere

Gibson, A. (2019). Free Speech and Safe Spaces: How Moderation Policies Shape Online Discussion Spaces. Social Media + Society, 5(1). doi: 10.1177/2 056305119832588

Habermas, J. (2015). Between Facts and Norms: Contributions to a Discourse Theory of Law and Democracy. Massachusetts: John Wiley \& Sons.

Harsin, J. (2017). Trump l'Eil: Is Trump's Post-Truth Communication Translatable? Contemporary French and Francophone Studies, 21(5), 512-522. doi: 10.1080/17 409292.2017.1436588

Herring, S. (2004). Computer-mediated Discourse Analysis: An Approach to Researching Online Communities. Designing for Virtual Communities in the Service of Learning. Cambridge: Cambridge University Press.

Holtz-Bacha, C. (2004). Germany: How the Private Life of Politicians got into the Media. Parliamentary Affairs, 57(1), 41-52. doi: 10.1093/pa/gsh004

Kantola, A. (2014). Mediatization of Power: Corporate CEOs in Flexible Capitalism. Nordicom Review, 35(2), 29-41. doi: 10.2478/nor-2014-0013

Langvardt, K. (2018). Regulating Online Content Moderation. Georgetown Law fournal, 106(5), 1353-1366. Retrieved from https://heinonline.org/HOL/Page?

handle=hein.journals/glj106\&id=1367\&div=\&collection $=$

Martyanov, D., \& Bykov, I. (2017). Ideological Segregation in the Russian Cyberspace: Evidences from St. Petersburg. In D. A. Alexandrov, A. V. Boukhanovsky, A. V. Chugunov, Y. Kabanov, \& O. Koltsova (Eds.), Communications in Computer and Information Science (pp. 259-269). Cham: Springer International Publishing. doi: 10.1007/978-3-319-69784-0_22

Mishankina, N., \& Zilberman, N. (2016). "Soviet" in the Space of Social Networks: A Form of Political Reflection. In A. V. Chugunov, R. Bolgov, Y. Kabanov, G. Kampis, \& M. Wimmer (Eds.), Communications in Computer and Information Science (pp. 45-50). Cham: Springer International Publishing. doi: 10.1007/978-3-319-49700-6_6

Newman, M. E. J., \& Girvan, M. (2004). Finding and evaluating community structure in networks. Physical Review E, 69(2), 026 113. doi: 10.1103/PhysRevE.69.026113

Rheingold, H. (2000). The Virtual Community, revised edition: Homesteading on the Electronic Frontier. Cambridge: MIT Press.

Schulz, W. (2004). Reconstructing Mediatization as an Analytical Concept. European fournal of Communication, 19(1), 87-101. doi: 10.1177/0 267323104040696

Suh, K.-S., Lee, S., Suh, E.-K., Lee, H., \& Lee, J. (2018). Online Comment Moderation Policies for Deliberative Discussion-Seed Comments and Identifiability. Fournal of the Association for Information Systems, 19(3), 182-208. Retrieved from https://aisel.aisnet.org/jais/vol19/iss3/2 
Sunstein, C. R. (2009). Going to Extremes: How Like Minds Unite and Divide. Oxford University Press.

Toepfl, F., \& Litvinenko, A. (2018). Transferring control from the backend to the frontend: A comparison of the discourse architectures of comment sections on news websites across the post-Soviet world. New Media \& Society, 20(8), 2844-2861. doi: $10.1177 / 1461444817733710$

Van Aelst, P., Sheafer, T., \& Stanyer, J. (2012). The personalization of mediated political communication: A review of concepts, operationalizations and key findings. Fournalism: Theory, Practice \& Criticism, 13(2), 203-220. doi: 10.1177/1464884911427 802

Wellman, B. (1998). Networks In The Global Village: Life In Contemporary Communities. Routledge.

Yun, G. W., Park, S.-Y., Holody, K., Yoon, K. S., \& Xie, S. (2013). Selective Moderation, Selective Responding, and Balkanization of the Blogosphere: A Field Experiment. Media Psychology, 16(3), 295-317. doi: 10.1080/15 213269.2012 .759462

Zheng, S. (2020). Chinese Fans' Patriotism Creating Quandary in the Digital Media Era. Galactica Media: Journal of Media Studies, 2(4), 87-111. doi: 10.46539/gmd.v2i4.87

Балахонская, Л. В., \& Быков, И. А. (2018). Виртуальная агрессия в политических блогах радиостанции «Эхо Москвы». Вестник Санкт-Петербургского университета. Язык и литература, 15(3), 492-506. doi: 10.21638/spbu09.2018.313

Мартьянов, Д. С. (Ред.). (2019). Управляемость и дискурс виртуальных сообществ в условиях политики постправды. Санкт-Петербург: ЭлекСис.

Суслов, С. И. (2016). Кластеры петербургских политических онлайн-сообществ в «ВКонтакте». Вестник Санкт-Петербургского университета. Социология, (4), 69-87. doi: 10.21638/11701/spbu12.2016.405

Щекотин, Е. В., Гойко, В. Л., Барышев, А. А., \& Викторович, К. В. (2017). Влияние парламентских выборов в России на мобилизацию сторонников непарламентской оппозиции. Вестник науки Сибири, (3), 90-107. Извлечено от http:// sjs2.tpu.ru/journal/article/view/1576 